\title{
$P$-wave velocity structure in the southernmost source region of the 2011 Tohoku earthquakes, off the Boso Peninsula, deduced by an ocean bottom seismographic survey
}

\author{
Kazuo Nakahigashi ${ }^{1}$, Masanao Shinohara ${ }^{1}$, Kimihiro Mochizuki ${ }^{1}$, Tomoaki Yamada ${ }^{1}$, Ryota Hino $^{2}$, \\ Toshinori Sato ${ }^{3}$, Kenji Uehira ${ }^{4 *}$, Yoshihiro Ito $^{2}$, Yoshio Murai ${ }^{5}$, and Toshihiko Kanazawa ${ }^{1 *}$ \\ Earthquake Research Institute, University of Tokyo, Tokyo 113-0032, Japan \\ ${ }^{2}$ Graduate School of Science, Tohoku University, Sendai 980-8578, Japan \\ ${ }^{3}$ Graduate School of Science, Chiba University, Chiba 263-8522, Japan \\ ${ }^{4}$ Institute of Seismology and Volcanology, Kyushu University, Shimabara 855-0843, Japan \\ ${ }^{5}$ Institute of Seismology and Volcanology, Hokkaido University, Sapporo 060-0810, Japan
}

(Received February 5, 2012; Revised May 9, 2012; Accepted June 17, 2012; Online published January 28, 2013)

\begin{abstract}
We present the result of a seismic experiment conducted using ocean bottom seismometers and controlled sources in the region off Ibaraki and the Boso Peninsula. This region is the southern edge of the rupture zone of the 2011 off the Pacific coast of Tohoku Earthquake. We estimated the $P$-wave seismic velocity structure beneath the profile using a 2-D ray-tracing method. The crustal structure in the southern area is more heterogeneous than that of the northern area. This heterogeneity is thought to be related with subducting the Philippine Sea plate (PHS). The plate boundary between the landward plate and the Pacific plate (PAC) is positioned at depths of 20 $\mathrm{km}$ at a distance of $170 \mathrm{~km}$ from the southern end of the profile. The subducting PHS is imaged on the southern part of the profile. However, we could not obtain a distinct image of the contact zone of PHS and PAC. The contact zone of PHS and PAC is estimated to have a large heterogeneity resulting from strong deformation due to the collision of the two plates. We infer that the termination of the rupture, and the large afterslip in the collision region, are caused by this strong heterogeneity.
\end{abstract}

Key words: Crustal structure, Philippine Sea plate, Pacific plate, The 2011 off the Pacific coast of Tohoku Earthquake, ocean bottom seismometer (OBS), plate boundary.

\section{Introduction}

The Japan Trench (JT) is one of the most active seismogenic zones in the world. The Pacific plate (PAC) is subducting beneath the northeastern Japan (NEJ) arc (Fig. 1). Large earthquakes in the forearc region of the NEJ arc have been recorded in the historical record. Since the 1980s, many seismic experiments using controlled sources and Ocean Bottom Seismometers (OBSs) have been conducted to study the seismic structure beneath the landward slope of the JT (e.g. Suyehiro et al., 1985; Takahashi et al., 2004; Mochizuki et al., 2008). The precise structure of the forearc region in the NEJ arc, including the subducting oceanic crust, has been obtained from these studies.

In the southernmost part of the JT, there is a trenchtrench-trench-type triple junction (Mckenzie and Morgan, 1969). The Philippine Sea plate (PHS) is subducting northwestward from the Sagami Trough and the PAC is subducting westward from the Japan and Izu-Ogasawara trenches

* Now at National Research Institute for Earth Science and Disaster Prevention, Tsukuba 305-0006, Japan.

Copyright (c) The Society of Geomagnetism and Earth, Planetary and Space Sciences (SGEPSS); The Seismological Society of Japan; The Volcanological Society of Japan; The Geodetic Society of Japan; The Japanese Society for Planetary Sciences; TERRAPUB.

doi:10.5047/eps.2012.06.006 (e.g. Seno, 1977; Ishida, 1992). The subduction of the PHS below the landward plate is also estimated from the existence of low-angle thrust-fault-type earthquakes which occur below this region. The thrust-type earthquakes can be grouped by slip vector direction. The earthquakes associated with the subduction of the PAC have a $P$-axis in the direction west or west-northwest, which is consistent with the relative plate motion of the PAC. Earthquakes occurring between the PHS and NEJ arc have a relatively shallow depth and are mainly observed below the Kanto-region. The direction of the $P$-axis is northwest, which is consistent with the direction of the subduction of the PHS. The PHS is suggested to overlay on the PAC in the Kanto-region including the Boso-peninsula. From the study for repeating earthquakes which have thrust-type mechanisms, it is inferred that the PHS is in contact with the PAC below the Boso-peninsula (Uchida et al., 2009). However, it is difficult to determine the exact position of the northern limit of the PHS off the Boso-peninsula due to a lack of seismicity in the marine area.

Various seismic events have occurred as a result of the subduction of the PAC and PHS beneath the NEJ arc. Slow slip events and devastating earthquakes such as the 1923 Kanto earthquake associated with the subduction of the PHS were known in the region off Boso-peninsula (e.g. Sato et al., 2005; Ozawa et al., 2007). In order to analyze these 


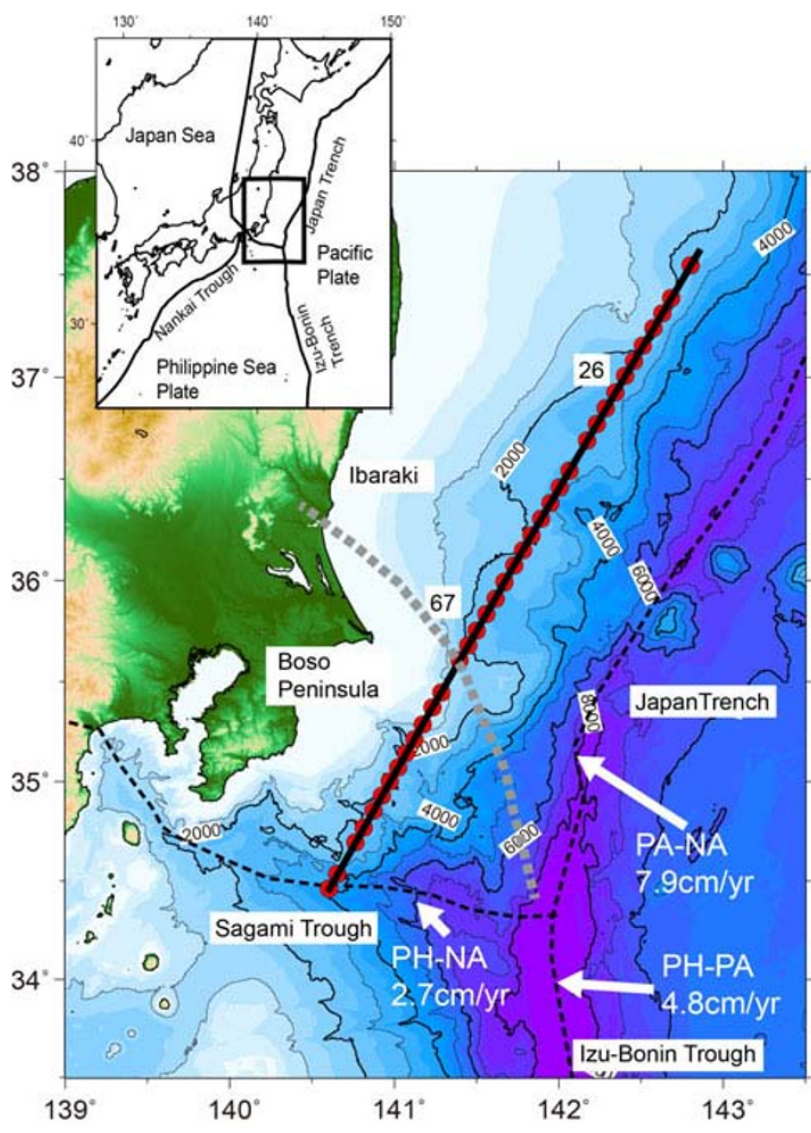

Fig. 1. Map showing bathymetry and location of the seismic survey in the southernmost part of the Japan Trench. Positions of the OBSs are marked by red solid circles. The thick solid line represents the survey line. Numerals indicate the OBS number. Dashed lines denote the axis of the Japan trench, Sagami trough, and Izu-Ogasawara trench. The bathymetric contour interval is $1000 \mathrm{~m}$. The inset shows the plate boundaries and survey area. The dashed grey line denotes the northeastern limit of the Philippine Sea plate according to Uchida et al. (2009). The white arrows indicate relative motion between the two plates at the plate boundary (Seno et al., 1993, 1996).

seismic events, it is necessary to know the crustal structure of the off-Boso region. Several seismic reflection surveys (e.g. Takeda et al., 2007; Kimura et al., 2009, 2010) and a refraction survey using OBSs (Hirata et al., 1992) have been conducted. These studies revealed a shallow structure in the off-Boso region, and the subduction of the PHS below the landward plate from the Sagami trough is imaged in the shallow region. However, the deep seismic structure of this region has not been obtained. In addition, little seismicity is observed at the plate boundary between the PHS and the landward plate below the off-Boso region. Therefore, there has been a controversy about the precise position of the tip of the PHS below the landward plate.

Moreover, the 2011 off the Pacific coast of Tohoku earthquake (hereafter, the 2011 Tohoku earthquake) $\left(M_{\mathrm{JMA}}=\right.$ 9.0) occurred in the forearc region of the JT on March 11, 2011 (Hirose et al., 2011). The source region of this earthquake is considered to spread to the off-Ibaraki and Boso region. The largest aftershock $(M=7.7)$ occurred thirty minutes after the mainshock in this region (Nishimura et al., 2011). Furthermore, the afterslip area of the mainshock reaches the off-Boso region (Ozawa et al., 2011). Deter- mination of the detailed seismic structure of the region off Ibaraki and Boso-peninsula is important for considering the spread of the source region of the 2011 Tohoku earthquake.

We investigate, therefore, the precise deep seismological structure beneath the landward slope off Ibaraki and the Boso Peninsula by a seismic survey using OBSs and explosives as seismic sources. In this paper, we present a twodimensional (2-D) $P$-wave velocity model along a $400-\mathrm{km}$ long profile on the southernmost part of the source region of the 2011 Tohoku earthquake.

\section{Experiment and Data Analysis}

In September, 2008, we conducted a seismic refraction experiment off Ibaraki and the Boso Peninsula using M/V Kaiko-maru No 5 (Offshore Operation Co., chartered by the Earthquake Research Institute (ERI), University of Tokyo) and R/V Hakuho-maru (Japan Agency for Marine-Earth Science and Technology). A seismic survey line with a length of $400 \mathrm{~km}$ was located on the landward slope along the JT and was oblique to the Sagami trough (Fig. 1). We deployed 31 short-period type OBSs, equipped with a three-component $4.5 \mathrm{~Hz}$ geophone on a leveling mechanism (Shinohara et al., 1993). During the seismic survey, a passive seismic experiment had been conducted using Long-Term OBSs (LT-OBSs) equipped with three-component velocity sensors whose natural frequencies were $1 \mathrm{~Hz}$ (Kanazawa et al., 2009) around the seismic survey line (Yamada et al., 2011), and 10 LT-OBSs were located on the survey line. Thus, a total of 41 OBSs at $10-\mathrm{km}$ spacing were used for the seismic survey. Due to problems with the recording system, the data of the 4 OBSs could not be used. All other stations yielded useful data. Explosives and airguns were fired as controlled seismic sources on the line. A charge size of each explosive source was $40 \mathrm{~kg}$ and the total number of shot was 134 . Four airguns with a total volume of 6000 cubic inches were fired at a spatial interval of approximately $150 \mathrm{~m}$. Record examples of the vertical component of OBS 67 and 26 for explosives and airguns are shown in Figs. 2 and 3, respectively. We can identify a large change in the apparent velocity of first arrivals in both sections. The signal-to-noise ratio decreases towards the southern part of the profile. First arrivals from the explosives can be recognized for OBS 67 at an offset distance up to about $200 \mathrm{~km}$ (Fig. 2).

The $P$-wave velocity model was constructed using the following steps. The direct tau-p mapping and the tau-sum inversion (Diebold and Stoffa, 1981; Stoffa et al., 1981; Shinohara et al., 1994) were applied to the airgun data to obtain a one-dimensional $P$-wave velocity structure of the shallow part just below each OBS. Next, we conducted a refraction tomography analysis (Fujie et al., 2006) using only first-arrival data from airgun and explosive records. From these analyses, a detailed structure of the shallow part, and an outline of the deep structure, were obtained. For the tomographic analysis, we defined a model space of $400 \mathrm{~km} \times 35 \mathrm{~km}$ comprising $10 \mathrm{~km} \times 2 \mathrm{~km}$ cells. The velocities of each cell were determined from 7338 first arrivals. Through this inversion, the root-mean-square (RMS) error of the first-arrival data was reduced from $1427 \mathrm{~ms}$ to 151 ms. Finally, we obtained the final crustal model by a for- 

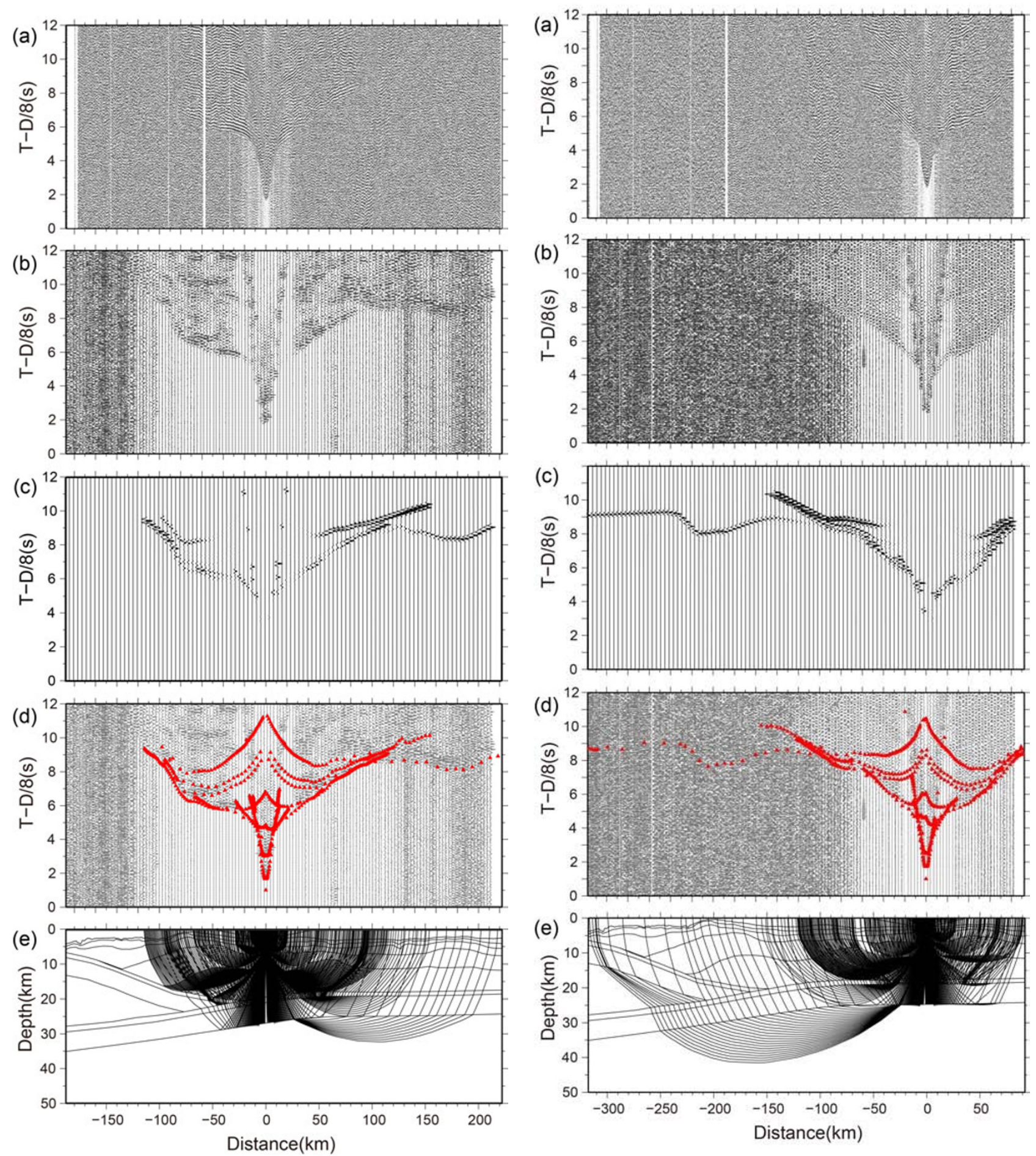

Fig. 2. (a) Observed airgun data recorded on the vertical component of OBS67. The vertical axis is the travel time reduced by $8 \mathrm{~km} / \mathrm{s}$. A band-pass filter $(5-15 \mathrm{~Hz})$ was applied to the observed data. Each trace is normalized to its maximum amplitude. (b) Observed explosive data recorded on the vertical component of OBS67. A band-pass filter (3-8 $\mathrm{Hz}$ ) was applied to the observed data. Each trace is normalized to its maximum amplitude. (c) Synthetic seismograms estimated from the final model using the ray theory. (d) Observed explosive data and the estimated travel time from the final velocity model. Red solid triangles denote the estimated travel time. (e) Ray diagram calculated using the final velocity model. The vertical axis is the depth from the sea level. The horizontal axes indicate the offset distance in kilometers between the OBS and shots. Its deployed position is indicated in Fig. 1.

Fig. 3. The same as Fig. 2, but for OBS26. Its deployed position is indicated in Fig. 1.

ward 2-D ray tracing method (Zelt and Smith, 1992). The model obtained by the tau-p method and tomography analysis was used as an initial model for the ray tracing method. We determined the $P$-wave velocity structure using first arrivals and later arrivals, and finally obtained the precise $P$ wave velocity structure up to a depth of $30 \mathrm{~km}$ (Fig. 4). The RMS error of first-, and later, arrival data calculated using the final model was $265 \mathrm{~ms}$ (Table 1). We also calculated synthetic seismograms using the estimated model and com- 


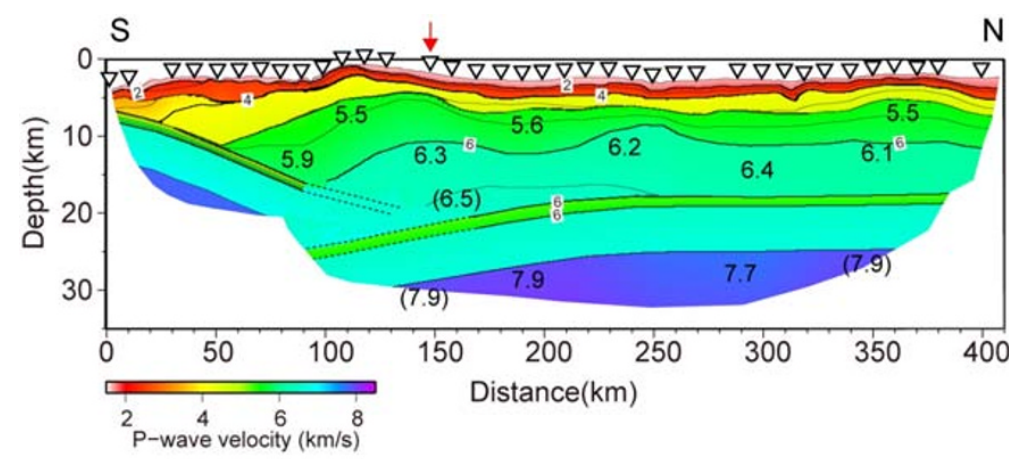

Fig. 4. The final velocity model. The numerals are $P$-wave velocities in $\mathrm{km} / \mathrm{s}$. The interval of the velocity contours is $0.4 \mathrm{~km} / \mathrm{s}$. The velocities are also color-coded. A blank region indicates no ray coverage. The vertical axis is the depth from the sea level. The horizontal axis is the distance from the southwestern end of the survey line. Triangles indicate the positions of OBSs. Interfaces between the plates are clearly recognized. The red arrow indicates the northeastern limit of the Philippine Sea plate according to Uchida et al. (2009).

Table 1. The root-mean-square error for the final model.

\begin{tabular}{c|cccc}
\hline Data type & $\begin{array}{c}\text { First and later } \\
\text { arrivals from } \\
\text { entire model }\end{array}$ & $\begin{array}{c}\text { First arrivals } \\
\text { from entire } \\
\text { model }\end{array}$ & $\begin{array}{c}\text { First and later } \\
\text { arrivals from } \\
\text { island arc crust }\end{array}$ & $\begin{array}{c}P_{n} \text { arrivals } \\
\text { from Pacific } \\
\text { plate }\end{array}$ \\
\hline RMS error (ms) & 263 & 239 & 265 & 268 \\
\hline
\end{tabular}

pared them with the observed data (Figs. 2 and 3).

To establish the reliability, we estimated the resolution of model parameters by an inversion algorithm. The resolution in the upper three layers is not calculated because the velocities were estimated precisely using the tau-p method. Resolution values greater than 0.5 are considered to be well resolved (Zelt and Smith, 1992). Figure 5(a) and (b) show the ray coverage and the resolution of the estimated velocity parameters, respectively. From the calculated resolution, the velocities shallower than $20 \mathrm{~km}$ are well resolved with a high resolution.

\section{Results and Discussion}

\subsection{Detailed $\boldsymbol{P}$-wave velocity structure and its implica-} tions

The shallow part of the structure can be divided into several layers based on velocity changes and vertical velocity gradients (Fig. 4). The sedimentary section varies in thickness from $4 \mathrm{~km}$ to $9 \mathrm{~km}$. The sedimentary layer which consists of three layers is present throughout the entire. The thickest sedimentary layer is found around a distance of $50 \mathrm{~km}$ from the southern end of the profile. The uppermost sedimentary layer and the second layer have a $P$-wave velocity of $1.6-1.8 \mathrm{~km} / \mathrm{s}$ and $2.3-2.7 \mathrm{~km} / \mathrm{s}$, respectively. These layers are a common feature among the JT forearc region and correspond to Tertiary/Quaternary sediments (e.g. Miura et al., 2005). The third sedimentary layer has a $P$ wave velocity of $3.8-4.6 \mathrm{~km} / \mathrm{s}$. This layer is thought to be a Pre-Oligocene layer (e.g. Miura et al., 2005). A layer with $P$-wave velocities of $5.4-5.9 \mathrm{~km} / \mathrm{s}$ underlies the sedimentary sections. The thickness of this layer varies from 2 to 9 $\mathrm{km}$. The depth of the top of this layer becomes shallow at a distance of approximately $110 \mathrm{~km}$ from the southern end of the profile. The 5.4-km/s layer corresponds to the upper crust of the landward plate. A layer with $P$-wave velocities of $6.1-6.5 \mathrm{~km} / \mathrm{s}$ underlies the upper crust in the landward plate. The thickness of this layer ranges from 6 to $10 \mathrm{~km}$. The $5.4-\mathrm{km} / \mathrm{s}$ layer and the $6.1-\mathrm{km} / \mathrm{s}$ layer are interpreted as the island arc crust because similar velocities are widely observed not only below inland areas, but also along the forearc region of the JT (e.g. Iwasaki et al., 2002; Miura et al., 2003; Ito et al., 2004). Compared with the southern part of the island arc crust, the northern part of crust has less lateral heterogeneity. This laterally homogeneous crustal structure in the northern part is consistent with previous studies (Miura et al., 2003, 2005).

Strong reflection waves were observed and were estimated to be reflected at a deep interface (Fig. 3). This significant deep interface is interpreted as the top of the subducting PAC. The subducting oceanic crust of the PAC is imaged beneath the island arc crust (Fig. 4). The plate boundary between the landward plate and the PAC is positioned at depths of $17 \mathrm{~km}$ at the northern end of the profile, and $20 \mathrm{~km}$ at a distance $170 \mathrm{~km}$ from the southern end of the profile. The PAC deepens towards the south from a distance of $200 \mathrm{~km}$ on the profile. The subducting PAC is in contact with the island arc crust. According to several studies, the contact zone between the island arc crust and the oceanic crust can be the rupture areas of a great earthquake with magnitude $>7$ (e.g. Nakanishi et al., 2004; Takahashi et al., 2004). Depths of the Moho in the oceanic crust of the PAC is $24-26 \mathrm{~km}$ below sea level in the northern part of the profile. The $P$-wave velocity of the PAC oceanic upper mantle is $7.7-7.9 \mathrm{~km} / \mathrm{s}$. The depth and $P$-wave velocity of the uppermost mantle $\left(P_{n}\right.$ velocity) of the PAC correspond with a previous study located at the landward slope along the JT (Miura et al., 2003). In contrast, the $P_{n}$ velocity of the PAC is slightly different from the result of Nishizawa et al. (2009). Their survey line was located perpendicular to our survey line. It is believed that the uppermost mantle in the Northwestern Pacific Basin exhibits a seismic anisotropy (e.g. Shinohara et al., 2008). The az- 
(a)

\section{S}

$\mathrm{N}$

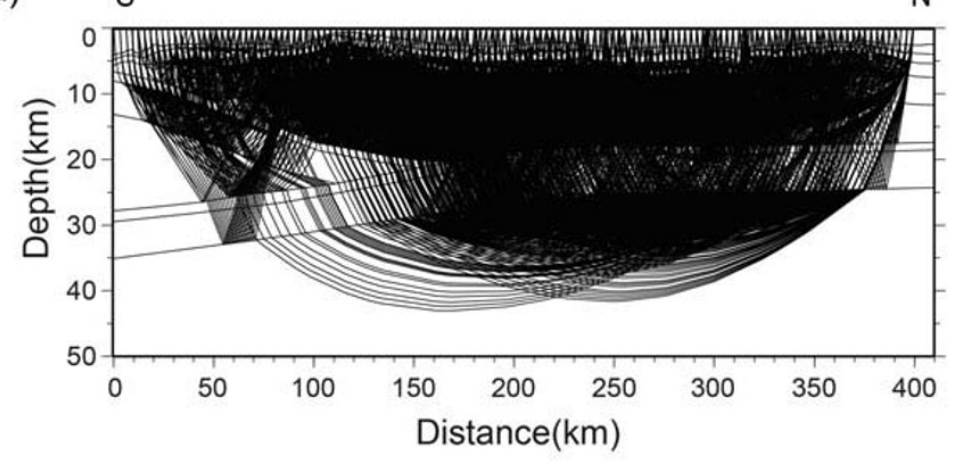

(b)

$\mathrm{S}$

$\mathrm{N}$

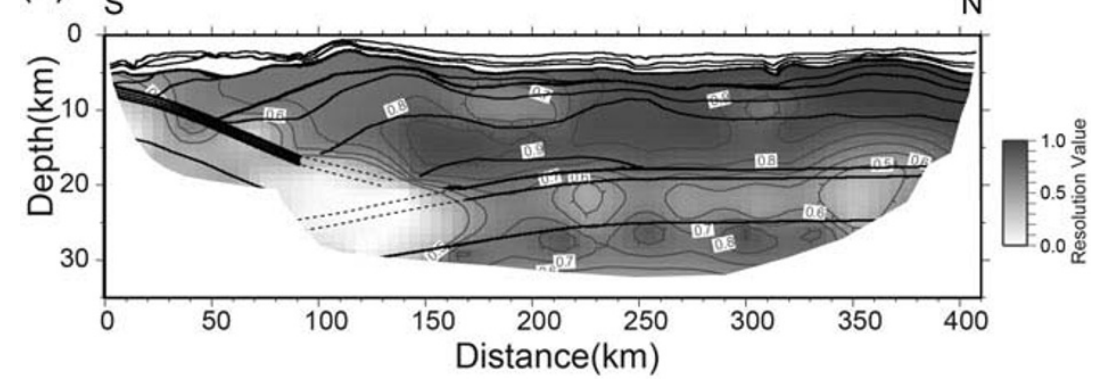

Fig. 5. (a) Ray diagrams of all OBS calculated by the travel time inversion. The black lines show all turning and reflected waves. (b) Resolution of the velocity nodes calculated by the travel time inversion. Resolution values are represented by a grey scale. The contour is drawn for the resolution greater than 0.5 . The contour interval is 0.1 . Resolution in the sedimentary layer is not calculated because the velocity was determined by the tau-p method.

imuthal anisotropy in the oceanic upper mantle appears to be aligned with the direction of spreading at the time of crustal generation rather than in the direction of present plate motions (e.g. Christensen, 1984). The fast direction of the $P_{n}$ velocity appears to be perpendicular to the lineation of magnetic anomalies. The magnetic lineation of PAC in the off Boso region is oblique to the JT (Nakanishi et al., 1989). There is a possibility that this difference in the velocity is affected by seismic anisotropy, which formed at the time of crustal generation.

In the southern part of the profile, we also observed reflected waves from a shallow interface (Fig. 2). This interface deepens toward the north, and is interpreted as the top of the subducting PHS. Position of the top of the PHS is consistent with the result of a previous seismic reflection survey in this area (Takeda et al., 2007). The crustal structure in the southern part of the landward plate is more heterogeneous than that in the northern part. The heterogeneity in the southern part is thought to be influenced by the subducting PHS plate.

Because the plate boundary between the PHS and the landward plate dips towards the north, an extension of the plate boundary reaches the top of the PAC. Uchida et al. (2010) investigated small repeating earthquakes which occur on the plate boundary between the PHS and the PAC, and estimated positions of the northeastern limit of the PHS. According to their results, the PHS is in contact with the PAC at distances from $0 \mathrm{~km}$ to $130 \mathrm{~km}$ on our profile. However, we could not resolve the structure of the contact region between the subducting PHS and the subducting PAC, since the reflection and refraction waves passing through this re- gion could not be identified clearly from the OBS records. A heterogeneity structure, due to the collision of the two plates, causes an indistinct seismic signal. We infer that the PHS collides with the PAC in this region.

Comparing the crustal structure with the seismic activities before the 2011 Tohoku earthquake (Yamada et al., 2011), there is no seismic activity in this region. Furthermore, Shinohara et al. (2012) shows that the aftershock activity of the 2011 Tohoku earthquake is not seen in the region. They also show that there is a high aftershock activity in front of the region, which we could not resolve (Fig. 6). Lack of seismic activities in the colliding region of the two plates and high seismic activities in the front of a tip of the collision zone are also seen at the Hidaka Collision Zone, central Hokkaido, Japan (Iwasaki et al., 2004). In addition, Shinohara et al. (2012) estimated several focal mechanisms of aftershocks, and there are earthquakes with a $P$-axis in the north-south direction in front of the uncertain region (Fig. 6). Consequently, we conclude that the subducting PHS exists in the region which we could not resolve, and the PHS collides with the PAC in this region. The colliding zone of the PHS and the PAC is expected to have a strong heterogeneity resulting from a large deformation.

\section{2 $P$-wave velocity structure and the 2011 Tohoku earthquake}

The 2011 Tohoku earthquake with a magnitude of 9 occurred at the plate boundary between the Pacific plate and the landward plate on March 11, 2011. The source region of the mainshock is estimated to spread over a region with a width of $500 \mathrm{~km}$ from the aftershock distribution. The rupture of the mainshock started off Miyagi and propagated 


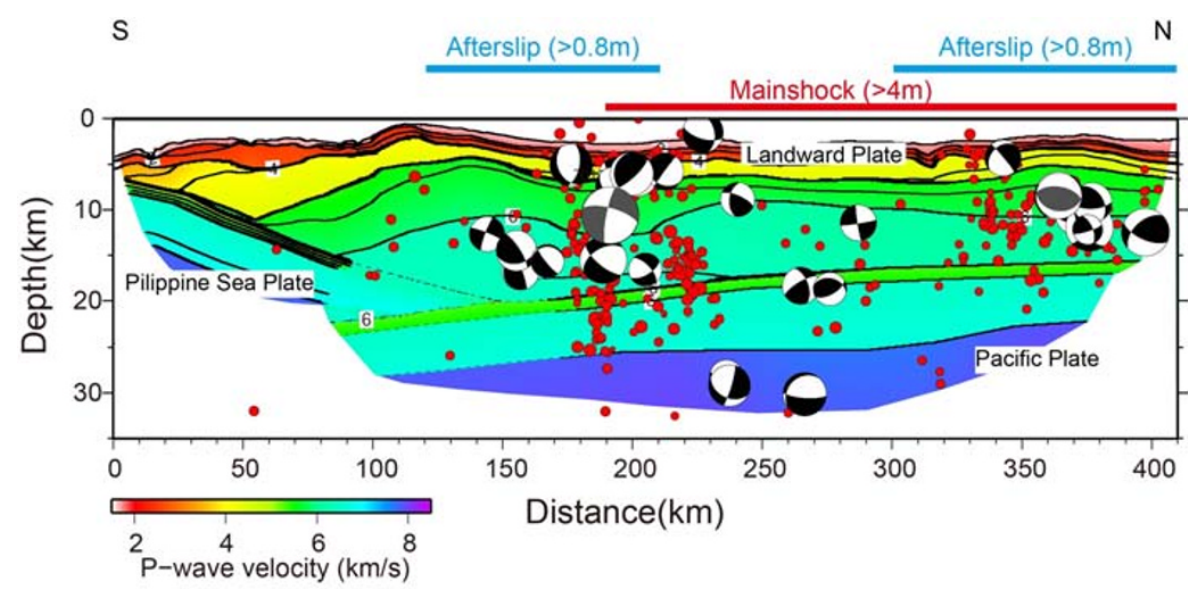

Fig. 6. The obtained $P$-wave velocity structures and the aftershock distribution (Shinohara et al., 2012) along the profile. The aftershocks within a 20-km-wide box on both sides of the profile are projected onto the seismic survey profile. Focal mechanisms determined by Shinohara et al. (2012) are also projected on the profile. Red circles indicate the hypocenters of the aftershocks, and diameters of circles correspond to magnitudes. The red and blue bars show the region which has a co-seismic slip greater than $4 \mathrm{~m}$ (Yoshida et al., 2011) and the region of the afterslip greater than $0.8 \mathrm{~m}$ as of December 2011 (Ozawa et al., 2011; Geospatial Information Authority of Japan, 2011).

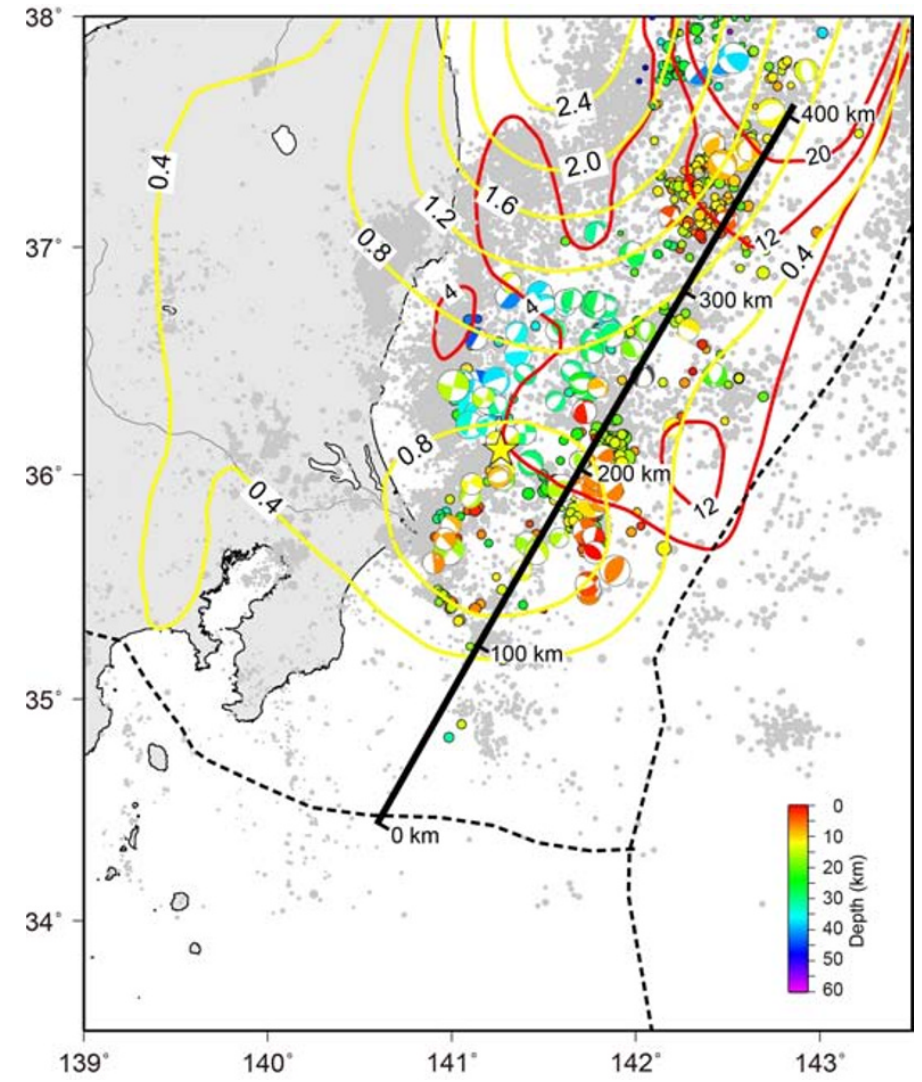

Fig. 7. Comparison of the position of the profile in this study with the aftershock epicenter distribution determined by the OBS network, focal mechanisms of aftershocks obtained by the OBS network (Shinohara et al., 2012) and by the automated moment tensor determination using the land seismic network (F-net) (Fukuyama et al., 1998), the slip distribution during the mainshock using strong motion data (Yoshida et al., 2011) and the slip distribution of the afterslip by the land GPS network as of December 2011 (Ozawa et al., 2011; Geospatial Information Authority of Japan, 2011). The red and yellow contours indicate the amount of co-seismic slips and afterslip, respectively. The solid circles denote the epicenters of aftershocks and color indicates the event depth. Grey circles denote epicenters of aftershocks determined by the JMA from March to June, 2011. The numbers along the profile represent the distance from the southern end.

to the off-Boso region. The southern edge of the rupture zone of the mainshock was positioned at a distance of approximately $200 \mathrm{~km}$ from the southern end of the survey profile from the studies of the rupture process (e.g. Yoshida et al., 2011) and the aftershock distribution deduced from the OBS data (Shinohara et al., 2011, 2012) (Figs. 6 and 7). Yoshida et al. (2011) estimated the source process of the 2011 mainshock from teleseismic $P$ waves and regional strong motion data. According to their results, a co-seismic slip greater than $4 \mathrm{~m}$ is estimated in the northern part of 
the profile from a distance of approximately $190 \mathrm{~km}$. In addition, Shinohara et al. $(2011,2012)$ determined the precise aftershock distribution by the urgent OBS observation. The aftershock activity near the plate boundary between the PAC and the landward plate was observed in the northern part of the profile from a distance of about $170 \mathrm{~km}$. The southern end of the seismically-active region of the aftershocks, and the co-seismic slip, corresponds to the contact region of the PHS and the PAC. A relationship between the heterogeneous structure and the area of seismogenic rupture is also reported in the Nankai trough (Kodaira et al., 2000).

After the occurrence of the 2011 Tohoku earthquake, post-seismic deformations were detected by the GPS network of Japan. Ozawa et al. (2011) estimated the afterslip distribution in and around the source region of the mainshock using GPS data. The Geospatial Information Authority of Japan continues the monitoring of crustal deformation on land using the GPS network and estimates the distribution of the afterslip. A large afterslip is estimated to overlap the coseismic slip region and extends to the surrounding region of the mainshock. A relatively large afterslip is estimated in the south of the source region. The large afterslip region in the south corresponds to the collision region between the PHS and the PAC (Figs. 6 and 7). The rupture of the mainshock sequence was terminated at the collision region of the PHS and the PAC, and the afterslip occurs in the collision zone. We infer that the termination of the rupture and the large afterslip in the collision region are caused by the strong heterogeneity resulting from the large deformation due to the collision.

\section{Conclusions}

We have conducted a seismic experiment using ocean bottom seismometers and controlled sources in the region off Ibaraki and the Boso Peninsula in 2008. We modeled the $P$-wave seismic velocity structure beneath the profile. The characteristics of the seismic velocity structure are as follows. (1) The crustal structure in the southern part is more heterogeneous than that of the northern part. (2) The northward dipping structure presents the subduction of the Philippine Sea plate in the southern part. (3) The subducting oceanic crust of the Pacific plate is in contact with the island arc crust at a depth of about $17 \mathrm{~km}$ in the northern region and a depth of $20 \mathrm{~km}$ at a distance of $170 \mathrm{~km}$ from the southern end of the profile. The geometry of the top of the PAC changes at a distance of about $200 \mathrm{~km}$ of the profile. (4) The contact zone of the Philippine Sea plate and the Pacific plate is not imaged clearly. It seems that the contact zone is characterized by a strong heterogeneity resulting from the large deformation.

The southern end of the seismically active region of the aftershocks, and the co-seismic slip, of the 2011 Tohoku earthquake correspond to the contact region of the Philippine Sea plate and the Pacific plate. The large afterslip region coincides with the collision region of the two plates. The termination of the mainshock rupture, and the large afterslip, in the collision region are thought to be caused by the collision of the two oceanic plates.

Acknowledgments. We would like to thank the officers and crew of M/V Kaiko-maru No. 5, and R/V Hakuho-maru. We also thank Messrs. S. Hashimoto, T. Yagi, and S. Suzuki for preparation of the OBS observation. We also thank Drs. A. Kuwano, T. Takanami, R. Arai, R. Azuma, R. Miura, T. Shinbo, Y. Yamamoto, Mses. H. Mizukami, M. Mizuno, Messrs. S. Amamiya, K. Ichijyo, K. Suzuki, and U. Yamashita, for the OBS survey and fruitful discussions. We wish to acknowledge the useful comments and suggestions from the editor, Dr. T. Okada, the reviewer, Dr. F. Klingelhoefer, and an anonymous reviewer. This study is partly supported by the Special Coordination Funds for the Promotion of Science and Technology (MEXT, Japan). Most of the figures were created using GMT (Wessel and Smith, 1999).

\section{References}

Christensen, N. I., The magnitude, symmetry and origin of upper mantle anisotropy based on fabric analyses of ultramafic tectonites, Geophys. J. R. Astron. Soc., 76, 89-111, 1984.

Diebold, J. B. and P. L. Stoffa, The travel time equation, tau-p mapping, and the inversion of common midpoint data, Geophysics, 46, 238-254, 1981.

Fujie, G., A. Ito, S. Kodaira, N. Takahashi, and Y. Kaneda, Confirming sharp bending of the Pacific plate in the northern Japan trench subduction zone by applying a travel time mapping method, Phys. Earth Planet. Inter., 157, 72-85, 2006.

Fukuyama, E., M. Ishida, D. S. Dreger, and H. Kawai, Automated seismic moment tensor determination by using on-line broadband seismic waveforms, Zisin, 51, 149-156, 1998 (in Japanese with English abstract).

Hirata, N., T. Narumi, T. Amishiki, H. Katao, Y. Kaiho, S. Kashiwara, R. Hino, H. Baba, H. Shiobara, S. Koresawa, M, Shinohara, A. Kubo, T. Kanazawa, J. Kasahara, and H. Kinoshita, Report on DELP 1989 Cruise in the TTT Junction Areas Part2: Upper Crustal Structure Near the Trench-Trench-Trench Triple Junction off Boso Peninsula, Japan, Bull. Earthq. Res. Inst. Univ., Tokyo, 67, 479-512, 1992.

Hirose, F., K. Miyaoka, N. Hayashimoto, T. Yamazaki, and M. Nakamura, Outline of the 2011 off the Pacific coast of Tohoku Earthquake $\left(M_{\mathrm{w}}\right.$ 9.0)-Seismicity: foreshocks, mainshock, aftershocks, and induced activity_, Earth Planets Space, 63, 513-518, 2011.

Ishida, M., Geometry and relative motion of the Philippine Sea plate and Pacific plate beneath the Kanto-Tokai district, Japan, J. Geophys. Res., 97, 453-489, 1992.

Ito, A., G. Fujie, T. Tsuru, S. Kodaira, A. Nakanishi, and Y. Kaneda, Fault plane geometry in the source region of the 1994 Sanriku-oki earthquake, Earth Planet. Sci. Lett., 223, 163-175, 2004.

Iwasaki, T., T. Yoshii, T. Ito, H. Sato, and N, Hirata, Seismological features of island arc crust as inferred from recent seismic expeditions in Japan, Tectonophysics, 355, 55-66, 2002.

Iwasaki, T., K. Adachi, T. Moriya, H. Miyamachi, T. Matsushima, K. Miyashita, T. Takeda, T. Taira, T. Yamada, and K. Ohtake, Upper and middle crustal deformation of an arc-arc collision across Hokkaido, Japan, inferred from seismic refraction/wide-angle reflection experiments, Tectonophysics, 388, 59-73, 2004.

Kanazawa, T., M. Shinohara, and H. Shiobara, Recent progress in seafloor earthquake observations and instruments in Japan, Zisin, 61, S55-S68, 2009 (in Japanese with English abstract).

Kimura, H., K. Kasahara, and T. Takeda, Subduction process of the Philippine Sea Plate off the Kanto district, central Japan, as revealed by plate structure and repeating earthquakes, Tectonophysics, 472, 18-27, 2009.

Kimura, H., T. Takeda, K. Obara, and K. Kazahara, Seismic Evidence for Active Underplating Below the Megathrust Earthquake Zone in Japan, Science, 329, doi:10.1126/science.1187115, 2010.

Kodaira, S., N., Takahashi, A. Nakanishi, S. Miura, and Y. Kaneda, Subducted Seamount Imaged in the Rupture Zone of the 1946 Nankaido Earthquake, Science, 289, doi:10.1126/science.289.5476.104, 2000.

Mckenzie, D. P. and W. J. Morgan, Evolution of triple junctions, Nature, 224, 125-133, 1969.

Miura, S., S. Kodaira, A. Nakanishi, T. Tsuru, N. Takahashi, N. Hirata, and Y. Kaneda, Structural characteristics controlling the seismicity of southern Japan Trench fore-arc region, revealed by ocean bottom seismographic data, Tectonophysics, 363, 79-102, 2003.

Miura, S., N. Takahashi, A. Nakanishi, T. Tsuru, S. Kodaira, and Y. Kaneda, Structural characteristics off Miyagi forearc region, the Japan Trench seismogenic zone, deduced from a wide-angle reflection and refraction study, Tectonophysics, 407, 165-188, 2005.

Mochizuki, K., T. Yamada, M. Shinohara, Y. Yamanaka, and T. Kanazawa, 
Weak interpolate coupling by seamounts and repeating M 7 earthquakes, Science, 321, 1194-1197, 2008.

Nakanishi, A., A. J. Smith, S. Miura, T. Tsuru, S. Kodaira, K. Obana, N. Takahashi, P. R. Cummins, and Y. Kaneda, Structural factors controlling the coseismic rupture zone of the 1973 Nemuro-Oki earthquake, the southern Kuril Trench seismogenic zone, J. Geophys. Res., 109, B05305, doi:10.1029/2003JB002573, 2004.

Nakanishi, M., K. Tamaki, and K. Kobayashi, Mesozoic magnetic anomaly lineations and seafloor spreading history of the northwestern Pacific, $J$. Geophys. Res., 94, 15,437-15,462, 1989.

Nishimura, T., H. Munekane, and H. Yarai, The 2011 off the Pacific coast of Tohoku Earthquake and its aftershocks observed by GEONET, Earth Planets Space, 63, 631-636, 2011.

Nishizawa, A., K. Kaneda, N. Watanabe, and M. Oikawa, Seismic structure of the subducting seamounts on the trench axis: Erimo Seamount and Daiichi-Kashima Seamount, northern and southern ends of the Japan Trench, Earth Planets Space, 61, e5-e8, 2009.

Ozawa, S., H. Suito, and M. Tobita, Occurrence of quasi-perodic slow-slip off the east coast of the Boso peninsula, Central Japan, Earth Planets Space, 59, 1241-1245, 2007.

Ozawa, S., T. Nishimura, H. Suito, T. Kobayashi, M. Tobita, and T. Imakiire, Coseismic and postseismic slip of the 2011 magnitude-9 TohokuOki earthquake, Nature, 475, doi:10.1038/nature10227, 2011.

Sato, H., N. Hirata, K. Koketsu, D. Okaya, S. Abe, R. Kobayashi, M. Matsubara, T. Iwasaki, T. Ito, T. Ikawa, T. Kawamura, K. Kasahara, and S. Harder, Earthquake source fault beneath Tokyo, Science, 309, doi:10.1126/science.1110489, 2005.

Seno, T., The instantaneous rotation vector of the Philippine Sea plate relative to the Eurasian plate, Tectonophysics, 42, 209-226, 1977.

Seno, T., S. Stein, and A. E. Gripp, A model for the motion of the Philippine Sea Plate consistent with NUVEL-1 and geological data, J. Geophys. Res., 98, 17,941-17,948, 1993.

Seno, T., T. Sakurai, and S. Stein, Can the Okhotsk plate be discriminated from the North American plate?, J. Geophys. Res., 101, 11,305-11,315, 1996.

Shinohara, M., K. Suyehiro, S. Matsuda, and K. Ozawa, Digital recording ocean bottom seismometer using portable digital audio tape recorder, $J$. Jpn. Soc. Mar. Surv. Technol., 5, 21-31, 1993 (in Japanese with English abstract).

Shinohara, M., N. Hirata, and N. Takahashi, High resolution velocity analysis of ocean bottom seismometer data by the tau-p method, Mar. Geophys. Res., 16, 185-199, 1994.

Shinohara, M., T. Fukano, T. Kanazawa, E. Araki, K. Suyehiro, M. Mochizuki, K. Nakahigashi, T. Yamada, and K. Mochizuki, Upper mantle and crustal seismic structure beneath the Northwestern Pacific Basin using a seafloor borehole broadband seismometer and ocean bottom seismometers, Phys. Earth Planet. Inter., 170, 95-106, 2008.

Shinohara, M., T. Yamada, K. Nakahigashi, S. Sakai, K. Mochizuki, K. Uehira, Y. Ito, R. Azuma, Y. Kaiho, T. No, H. Shiobara, R. Hino, Y. Murai, H. Yakiawra, T. Sato, Y. Machida, T. Shinbo, T. Isse, H. Miyamachi, K. Obana, N. Takahashi, S. Kodaira, Y. Kaneda, K. Hirata,
S. Yoshikawa, K. Obara, T. Iwasaki, and Hirata, Aftershock observation of the 2011 off the Pacific coast of Tohoku Earthquake by using ocean bottom seismometer network, Earth Planets Space, 63, 835-840, 2011. Shinohara, M., Y. Machida, T. Yamada, K. Nakahigashi, T. Shinbo, K. Mochizuki, Y. Murai, R. Hino, Y. Ito, T. Sato, H. Shiobara, K. Uehira, H Yakiwara, K. Obana, N. Takahashi, S. Kodaira, K. Hirata, H. Tsushima, and T. Iwasaki, Precise aftershock distribution of the 2011 off the Pacific coast of Tohoku Earthquake revealed by an ocean-bottom seismometer network, Earth Planets Space, 64, this issue, 1137-1148, 2012.

Stoffa, P. L., P. Buhl, J. B. Diebold, and F. Wenzel, Direct mapping of seismic data to the domain of intercept time and ray parameter, Geophysics, 46, 255-267, 1981

Suyehiro, K., T. Kanazawa, A. Nishizawa, and H. Shimamura, Crustal structure beneath the inner trench slope of the Japan Trench, Tectonophysics, 112, 115-191, 1985.

Takahashi, N., S. Kodaira, T. Tsuru, J.-O. Park, Y. Kaneda, K. Suyehiro, H. Kinoshita, S. Abe, M. Nishino, and R. Hino, Seismic structure and seismogenesis off Sanriku region, northeastern Japan, Geophys. J. Int., 159, 129-145, 2004.

Takeda, T., K. Kasahara, and H. Kimura, Geometry of the Philippines Sea plate in and around the Sagami trough-Digital restoration from paper records of multi-channel seismic data-, Earth Monthly, 57, 115-123, 2007 (in Japanese).

Uchida, N., J. Nakajima, A. Hasegawa, and T. Matsuzawa, What controls interplate coupling?: Evidence for abrupt change in coupling across a border between two overlying plates in the NE Japan subduction zone, Earth Planet. Sci. Lett., 283, 111-121, 2009.

Uchida, N., T. Matsuzawa, J. Nakajima, and A. Hasegawa, Subduction of a wedge-shaped Philippine Sea plate beneath Kanto, central Japan, estimated from converted waves and small repeating earthquakes, $J$. Geophys. Res., 115, doi:10.1029/2009JB006797, 2010.

Wessel, P. and W. H. F. Smith, Free software helps map and display data, Eos Trans. AGU, 72, 441, 1991.

Yamada, T., K. Nakahigashi, A. Kuwano, K. Mochizuki, S. Sakai, M. Shinohara, R. Hino, Y. Murai, T. Takanami, and T. Kanazawa, Spatial distribution of earthquakes off the east coast of the Kanto region along the Japan Trench deduced from ocean bottom seismographic observations and their relations with the aftershock sequence of the 2011 off the Pacific coast of Tohoku Earthquake, Earth Planets Space, 63, 841-845, 2011

Yoshida, Y., H. Ueno, D. Muto, and S. Aoki, Source process of the 2011 off the Pacific coast of Tohoku Earthquake with the combination of teleseismic and strong motion data, Earth Planets Space, 63, 565-569, 2011

Zelt, C. A. and R. B. Smith, Seismic travel time inversion for 2-D crustal velocity structure, Geophys. J. Int., 108, 16-34, 1992.

K. Nakahigashi (e-mail: kazuo@eri.u-tokyo.ac.jp), M. Shinohara, K. Mochizuki, T. Yamada, R. Hino, T. Sato, K. Uehira, Y. Ito, Y. Murai, and T. Kanazawa 